\title{
Penentuan Kriteria Pengunjung dalam Pemilihan Green Hotel di Kota Bandung Menggunakan Metode Discrete Choice Experiment dengan Desain Choice Sets Kombinatorial
}

\author{
Sheila Ghazia Shofwani*, Abdul Kudus \\ Prodi Statistika, Fakultas Matematika dan Ilmu Pengetahuan Alam, \\ Universitas Islam Bandung, Indonesia. \\ *sheilaghazia@gmail.com, abdulkudus@unisba.ac.id
}

\begin{abstract}
This research discusses about planning of guest formulation in the selection of environmentally green hotels by using a $2 \mathrm{k}-\mathrm{p}$ factorial fractional design and combinatorial choice sets on the Discrete Choice Experiment method. Discrete Choice Experiments is a quantitative method for survey-based respondents' preference assessment. This method asks respondents to choose the preferred choice from several alternative choices provided. With this method the authors will apply to the case of green hotel selection, because currently in the United States, investors are beginning to look at green building opportunities as a long-term investment in accordance with the operational costs of green buildings that are more efficient than conventional buildings. The concept of green building is one of the efforts to save energy that can be applied to a building. The material of this study is primary data by distributing questionnaires to respondents using voluntary sampling techniques. In this study, there are 8 independent variables consisting of 5 attribute variables and 3 respondent identity variables. This study aims to determine the criteria for visitors in choosing the most desirable green hotel. The results of this study are the results of green hotel research that is most sought after by visitors, namely hotels with quality luxury rooms, toiletries provided, visitors are required to improve the environment, there is the practice of using plastic on product packaging, and there is the use of lamps as well as energy-saving equipment. After further analysis of the demographics of respondents regarding the preference of the selected green hotel criteria for each respondent, and the results obtained at the time, gender, occupation and experience of staying in a green hotel together are not related to the involvement of the selected green hotel criteria chosen from each respondent.
\end{abstract}

Keywords: discrete choice experiment, fractional factorial, conditional logistic regression

\begin{abstract}
Abstrak. Skripsi ini membahas mengenai penentuan rancangan kriteria pengunjung dalam pemilihan hotel ramah lingkungan (green hotel) dengan menggunakan desain fractional factorial 2k-p dan choice sets kombinatorial pada metode Discrete Choice Experiment. Discrete Choice Experiment merupakan metode kuantitatif untuk menilai suatu preferensi seorang responden yang berbasis survei. Metode ini meminta responden untuk memilih pilihan yang diminati dari beberapa alternatif pilihan yang disediakan. Dengan metode ini penulis akan melakukan penerapan pada kasus pemilihan kriteria green hotel, karena saat ini di Amerika Serikat, para investor mulai melirik peluang green building sebagai investasi jangka panjang dikarenakan biaya operasional green building yang lebih hemat dibandingkan bangunan konvensional. Konsep green building merupakan salah satu upaya penghematan energi yang dapat diterapkan pada suatu gedung. Bahan dari penelitian ini merupakan data primer dengan melakukan penyebaran kuesioner kepada responden dengan menggunakan teknik sampling sukarela. Pada penelitian ini, terdapat 8 variabel independen yang terdiri dari 5 variabel atribut dan 3 variabel identitas responden. Penelitian ini bertujuan untuk mengetahui kriteria pengunjung dalam memilih green hotel yang paling diminati. Hasil dari penelitian ini adalah didapatkan kriteria green hotel yang paling diminati oleh pengunjung yaitu hotel dengan kualitas kamar mewah, perlengkapan mandi disediakan, pengunjung diwajibkan untuk menjaga lingkungan, ada praktik penggunaan plastik pada kemasan produk, dan ada penggunaan lampu juga peralatan hemat energi. Setelah itu dilakukan analisis lanjutan mengenai pengaruh dari demografi responden terhadap banyaknya keterpilihan kriteria green hotel terpilih pada setiap responden, dan diperoleh hasil bahwa usia, jenis kelamin, pekerjaan dan pengalaman menginap di green hotel secara bersama-sama tidak berpengaruh terhadap banyaknya keterpilihan kriteria green hotel terpilih dari setiap responden.
\end{abstract}

Kata Kunci: eksperimen pilihan diskrit, regresi logistik bersyarat, faktorial fraksional 


\section{A. Pendahuluan}

Dalam menjalani kehidupan, manusia pasti akan dihadapkan pada beberapa pilihan. Suatu pilihan dipilih jika pilihan tersebut dapat menguntungkan bagi pengambil keputusan atau dapat juga dipilih karena memiliki risiko paling rendah. Salah satu metode yang dapat digunakan untuk mengetahui preferensi adalah dengan menggunakan metode conjoint analysis. Terdapat dua jenis conjoint analysis yang sering digunakan, yaitu traditional conjoint dan choice based conjoint atau yang sering disebut dengan Discrete Choice Experiment (DCE).

Kebutuhan akan Discrete Choice Experiment semakin dirasakan dalam berbagai bidang. Terutama dalam bidang ekonomi bisnis yang mana dengan digunakannya metode ini maka penyedia barang maupun jasa dapat melihat ketertarikan konsumen terhadap desain suatu produk atau jasa yang di produksinya. Dalam skripsi ini akan dilakukan penerapan metode Discrete Choice Experiment pada kasus pemilihan kriteria green hotel.

Discrete Choice Experiment adalah metode yang melibatkan pembangkitan dan analisis data pilihan yang diimplementasikan dalam data survei. Discrete Choice Experiment merupakan metode kuantitatif untuk menilai suatu preferensi seorang responden yang berbasis survei. Metode ini meminta responden untuk memilih pilihan yang diminati dari beberapa pasang alternatif pilihan yang disediakan yang disebut sebagai choice sets. Agar dapat menentukan ke konsistenan responden dalam memilih maka disediakan beberapa choice sets yang mempunyai alternatif pilihan yang berbeda. Berdasarkan pemaparan pada pendahuluan, penelitian ini ditujukan:

1. Untuk mengetahui kriteria green hotel yang diminati oleh pengunjung dengan menggunakan analisis conditional logistic regression pada metode Discrete Choice Experiment.

2. Untuk mengidentifikasi pengaruh dari variabel karakteristik (demografi) responden terhadap kumulatif keterpilihan alternatif yang mempunyai nilai utilitas tertinggi dari setiap menggunakan analisis regresi logistik binomial.

\section{B. Landasan Teori}

\section{Discrete Choice Experiment}

Dalam percobaan pilihan, sebanyak $\mathrm{n}$ responden disajikan dalam serangkaian perangkat pilihan, dan untuk setiap perangkat mereka diminta untuk memilih pilihan yang mereka anggap terbaik. Dengan Discrete Choice Experiment, responden secara implisit harus mempertimbangkan alternatif lain dalam set pilihan ketika membuat pilihan. Oleh karena itu DCE cocok untuk mendeteksi pengaruh ketersediaan alternatif lain terhadap daya tarik suatu produk ataupun jasa. DCE merupakan metodologi dalam analisis eksperimen dengan mengkarakterisasi hubungan antara atribut dengan preferensi konsumen yang berbasis survei. Hasil utama dari DCE merupakan desain dari barang ataupun jasa yang disukai oleh sebagian besar responden, tentunya dengan nilai utilitas yang tertinggi.

Vij adalah fungsi dari p buah atribut, maka:

$V_{i j}=\beta_{0}+\beta_{1} X_{i 1 j}+\beta_{2} X_{i 2 j}+\ldots+\beta_{j} X_{i j}$

Sehingga rumus utilitas adalah:

$$
\begin{aligned}
& U_{i j}=V_{i j}+\varepsilon_{i j} \quad \text { dengan } U_{i j} \neq V_{i j} \\
& \boldsymbol{U}_{\boldsymbol{i j}}=\boldsymbol{\beta}_{\mathbf{0}}+\boldsymbol{\beta}_{\mathbf{1}} \boldsymbol{X}_{\boldsymbol{i 1 j}}+\boldsymbol{\beta}_{\mathbf{2}} \boldsymbol{X}_{\boldsymbol{i} \mathbf{2}}+\ldots+\boldsymbol{\beta}_{\boldsymbol{j}} \boldsymbol{X}_{\boldsymbol{i} \boldsymbol{j} \boldsymbol{j}}+\boldsymbol{\varepsilon}_{\boldsymbol{i j}}
\end{aligned}
$$

Menurut Lanscar dkk. (2017), alternatif ditentukan oleh sekumpulan variabel yang secara individual dinilai/dipilih oleh responden dengan maksud untuk mengevaluasi produk secara keseluruhan. Sebuah alternatif dapat mewakili sebuah produk, tindakan, atau opsi lainnya. Menurut definisi, setiap pilihan adalah terbuat dari serangkaian alternatif non-kosong. Pada metode DCE yang harus dilakukan terlebih dahulu yaitu menentukan alternatif yang akan digunakan pada penelitian. Alternatif ini ditentukan oleh sekumpulan taraf dari beberapa atribut. Dimana alternatif-alternatif tersebut, kemudian akan ditawarkan kepada responden dengan cara menyusunnya kedalam choice set.

Menurut Lanscar et al. (2017), choice set adalah set pilihan yang berisi dua atau lebih 
alternatif. Variasi dari struktur seperti ini termasuk suatu cara yang ditawarkan kepada responden yang membuat responden berusaha untuk mempertahankan apa yang mereka minati saat ini, sehingga peneliti harus menentukan alternatif apa yang cukup menarik untuk membuat responden beralih dari apa yang mereka minati. Kombinatorial adalah cabang matematika yang mempelajari pengaturan objek-objek. Solusi yang ingin diperoleh dengan kombinatorial ini adalah jumlah cara pengaturan objek-objek tertentu di dalam himpunannya. Salah satu cara dari kombinatorial adalah kombinasi.

$$
\left(\begin{array}{l}
n \\
r
\end{array}\right)=\frac{n !}{r !(n-r) !}
$$

\section{Logistic Regression}

Menurut Hosmer dkk. (2013) regresi logistik merupakan suatu metode analisis data yang menggambarkan hubungan antara satu variabel tak bebas (dependen) yang memiliki dua kategori atau lebih dengan satu atau lebih variabel bebas (independen). Regresi logistik biasanya digunakan untuk memprediksi variabel yang bersifat kategorik (biasanya dikotomi) oleh seperangkat variabel prediktor.

Karena variabel responnya menghasilkan dua kategori yang bernilai 0 dan 1, maka akan mengikuti distribusi Bernoulli. Jika $Y_{i}$ berdistribusi Bernoulli dengan parameter $\pi$ maka distribusi peluang dapat ditulis sebagai berikut:

$$
P\left(Y_{i}=y_{i}\right)=\left[\pi_{i}\right]^{y_{i}}\left[1-\pi_{i}\right]^{1-y_{i}} \quad \text { dengan } Y_{i}=0,1
$$

Jika ada $\mathrm{n}$ individu yang di ujikan, sedangkan $\mathrm{R}_{\mathrm{i}}$ variabel acak individu ke-i $(i=1,2, \ldots, n)$ dengan $\mathrm{R}_{\mathrm{i}}$ masing-masing berdistribusi Bernouli dan $\mathrm{j}(j=1,2, \ldots, p)$ merupakan banyaknya variabel penjelas atau faktor yang diamati $\left(X_{1}, X_{2}, \ldots, X_{p}\right)$. Jika $Y$ adalah banyaknya individu yang lulus hidup diantara $n$ yang diujikan maka $Y$ merupakan variabel acak yang merupakan jumlah dari kejadian Bernoulli dan diasumsikan setiap kejadian independent satu sama lain. Peluang kejadian $\mathrm{Y}$ individu dimana $(y \leq n)$ yang lulus hidup dari $\mathrm{n}$ individu yang diujikan adalah:

$$
P(Y=y)=\left(\begin{array}{l}
n \\
y
\end{array}\right) p^{y}(1-p)^{n-y} \quad \text { untuk } \mathrm{y}=0,1, \ldots, \mathrm{n}
$$

Dalam regresi logistik sering kali ditemukan variabel-variabel independen yang bersifat individual-specific tetapi harus diketahui bahwa adapula variabel-variabel independen yang bersifat choice-specific. Variabel independen yang bersifat choice-specific atau disebut juga dengan alternative-specific adalah variabel independen yang diukur dengan ciri yang dipilih yang diduga berpengaruh terhadap keputusan pilihan seorang responden. Model conditional logit yaitu ketika variabel-variabel independen nya mengandung variabel yang bersifat choicespecific. Variabel independen yang bersifat choice-specific adalah bahwa setiap taraf atau level variabel independen yang akan diteliti oleh peneliti ini sudah ditentukan oleh peneliti. Dalam regresi logistik nilai kemungkinan satu pengamatan ditunjukan dengan:

$P\left(Y_{i j}=1 \mid x_{i j}\right)=\frac{\exp \left(x_{i j} \beta^{\prime}\right)}{1+\exp \left(x_{i j} \beta^{\prime}\right)}$ dimana $X_{i j}$ merupakan nilai-nilai prediksi yang sesuai. Akan tetapi dalam conditional logistic regression, peluang individu ke- $i$ memilih pilihan ke- $j$ dari suatu kumpulan pilihan yang tergabung dalam himpunan $C_{i}$ atau dalam suatu choice-set adalah sebagai berikut:

$$
P\left(Y_{i j}=1 \mid x_{i j}\right)=\frac{\exp \left(x_{i j} \beta^{\prime}\right)}{\sum_{k \in c_{i}} \exp \left(x_{i j} \beta^{\prime}\right)}
$$

\section{Green Hotel}

Hotel ramah lingkungan merupakan suatu hotel yang dibangun dengan mempertimbangkan lingkungan, penggunaan energi, dan sumber daya yang digunakan. Desain Hotel ramah lingkungan dibangun dengan mempertimbangkan hubungan timbal balik antara manusia dengan alam dan lingkunganya, dimana desain menjadi satu dengan budaya lokal serta lingkungan setempat (Frick \& Suskiyatno, 1998).

Menurut Bromberek (2009) design green hotel juga harus semininimal mungkin dalam menghasilkan polusi, limbah pembuangan, serta kerusakan pada lingkungan setempat. Tujuan green hotel adalah membangun dengan dampak positif yang berkelanjutan. Pembangunannya 
harus menghindari rancangan yang dapat merusak atau merubah lingkungan setempat.

Dalam studi ini, green hotel didefinisikan sebagai hotel yang mengambil tanggung jawab untuk meminimalkan dampak lingkungan dan mengadopsi pendekatan berorientasi lingkungan terhadap tanah, penggunaan sumber daya, pembelian, operasi, dan manajemen.

\section{Alur Penelitian}

Penelitian ini dilakukan melalui beberapa tahapan sebagai berikut:

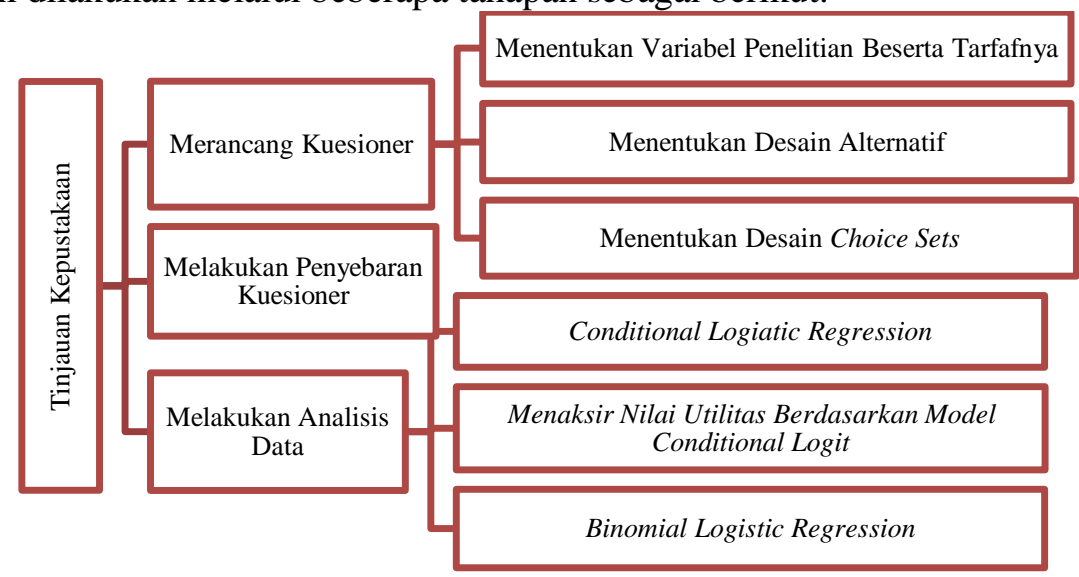

Gambar 1. Alur Penelitian

\section{Survey Instrument}

Berikut merupakan beberapa atribut yang dikutip dari Chu dan Choi (2000):

1. Kualitas Kamar

Ukuran kamar hotel, tingkat kebersihan dan kenyamanan

- Kamar Standar dengan tempat tidur ganda $15 \mathrm{~m} 2$, Kenyamanan biasa tapi bersih.

- Kamar Mewah dengan tempat tidur ganda $21 \mathrm{~m} 2$, Kamar yang sangat bersih dan nyaman, terawat dengan baik

2. Perlengkapan Mandi

Ketersediaan perlengkapan mandi pribadi, seperti pasta gigi, sikat gigi, sabun, atau sampo, dll.

- Penyediaan Peralatan mandi pribadi tidak disediakan.

- Penyediaan peralatan mandi pribadi disediakan.

3. Perilaku Ramah Lingkungan

Sejauh mana partisipasi tamu dalam perilaku lingkungan disarankan atau diminta.

- Pengunjung tidak diwajibkan untuk menjaga lingkungan, yaitu tidak ada tindakan konservasi air atau listrik. Suhu kamar tidak tetap.

- Pengunjung diwajibkan untuk menjaga lingkungan dengan konservasi air dan listrik. Suhu kamar harus tetap pada $26-27^{\circ} \mathrm{C}$.

4. Kualitas Pelayanan

Apakah pemberian layanan dan kualitas produk akan dipengaruhi oleh praktik manajemen lingkungan.

- Tidak ada penggunaan plastik pada kemasan produk.

- Ada penggunaan plastik pada kemasan produk.

5. Ukuran Penghijauan

Tingkat penerapan praktik lingkungan, fasilitas, dan peralatan di hotel.

- Tidak ada penggunaan lampu dan peralatan hemat energi.

- Ada penggunaan lampu dan peralatan hemat energi.

Variabel bebas kriteria green hotel beserta tarafnya digunakan dalam penentuan desain alternatif. Desain alternatif yang digunakan dalam penelitian ini adalah fractional factorial $2^{k-p}$. Sebelum menentukan jumlah alternatif yang akan digunakan, yang harus dilakukan 
terlebih dahulu yaitu menentukan jumlah full factorial $2^{k}$. Pada kasus rancangan pilihan pengunjung dalam memilih green hotel digunakan sebanyak 5 faktor $(\mathrm{k}=5)$ dengan masingmasing faktor mempunyai dua taraf. Dimana berdasarkan rumus alternatif full factorial $2^{\mathrm{k}}$ akan didapatkan jumlah alternatif sebanyak:

$$
2^{\mathrm{k}}=2^{5}=32 \text { alternatif }
$$

Pada percobaan full factorial $2^{5}$ akan menghasilkan sebanyak 32 kombinasi perlakuan yang disebut dengan alternatif. Ternyata faktor/variabel yang digunakan terlalu banyak, maka akan berakibat pada banyakrnya jumlah alternatif yang akan disajikan. Hal ini akan menyulitkan responden dalam melakukan evaluasi. Oleh karena keterbatasan waktu, tenaga dan biaya maka akan dilakukan reduksi pada 32 alternatif yang disajikan dengan tujuan tetap bisa menaksir efek utama variabel bebas, maka diambil seperempatnya dari rancangan full factorial $2^{5}$ dengan menggunakan rancangan fractional factorial $2^{5-2}$. Alternatif-alternatif yang terambil dari rancangan full factorial $2^{5}$ membentuk sebuah rancangan fractional factorial $2^{5-p}$. Berdasarkan rumus fraksi $\left(\frac{1}{2}\right)^{p}$ dengan $\mathrm{p}=2$ akan membentuk fraksi $\left(\frac{1}{2}\right)^{2}=\frac{1}{4}$ (seperempat). Alternatifalternatif yang terambil dari rancangan full factorial $2^{5}$ membentuk sebuah rancangan fractional factorial $2^{5-2}$ yang akan menghasilkan sebanyak,

\section{$2^{5-2}=2^{3}=8$ alternatif}

Diketahui bahwa pada rancangan fractional factorial $2^{5-2}$ menghasilkan sebanyak 8 alternatif dan ukuran choice sets sebanyak dua buah, maka sesuai dengan rumus choice sets kombinatorial didapatkan jumlah choice sets sebanyak $\left(\begin{array}{l}n \\ r\end{array}\right)=\left(\begin{array}{l}8 \\ 2\end{array}\right)=\frac{8 !}{2 !(8-2) !}=28$ choice sets. Yang kemudian setiap alternatif dipasang-pasangkan sehingga terdapat sebanyak 28 pasangan pilihan.

Dibawah ini disediakan contoh choice-sets dari sebuah kuesiner yang berisi beberapa pertanyaan terkait preferensi responden/konsumen dalam memilih green hotel yang diminati dalam bentuk seperti berikut:

Tabel 1. Contoh Coice-sets

\begin{tabular}{|c|c|}
\hline PILIHAN 1 & PILIHAN 2 \\
\hline Kualitas kamar STANDAR \\
Perlengkapan mandi TIDAK \\
DISEDIAKAN \\
$\begin{array}{c}\text { Kengunjung DIWAJIBKAN untuk kamar MEWAH } \\
\text { menjaga lingkungan } \\
\text { ADA Penggunaan plastik pada kemasan } \\
\text { produk } \\
\begin{array}{c}\text { TIDAK ADA penggunaan lampu dan } \\
\text { peralatan hemat energi }\end{array}\end{array}$ & $\begin{array}{c}\text { Pengunjung TIDAK DIWAJIBKAN untuk menjaga } \\
\text { lingkungan }\end{array}$ \\
\hline $\mathrm{V}$ & ADA penggunan lampu dan peralatan hemat energi \\
\hline
\end{tabular}

Petunjuk pengisiannya dengan memberikan tanda centang $(\sqrt{ })$ pada pilihan kolom kriteria green hotel yang diminati.

\section{Hasil Penelitian dan Pembahasan}

Data yang digunakan merupakan data primer mengenai penentuan kriteria Green Hotel di Kota Bandung yang diperoleh dari hasil penyebaran kuesioner. Data yang sudah didapatkan kemudian direkap dan diinput kedalam software Microsoft Excel berikut ini data berdasarkan kuesioner kriteria green hotel yang diminati oleh masyarakat di Kota Bandung disajikan pada Tabel berikut: 
Dari data diatas dilakukan pengujian untuk menentuka nilai utilitas dari setiap alternatif yang mana nantinya alternatif yang mempunyai nilai utilitas terbesar merupakan alternatif terpilih sebagai kriteria pengunjung. Analisis yang dilakukan adalah conditional logistic regression analysis yang mana hasil output software sebagai berikut:

Tabel 2. Data Mengenai Kriteria Green Hotel Yang Diminati Oleh Masyarakat Di Kota Bandung

\begin{tabular}{|c|c|c|c|c|c|c|c|c|c|c|c|c|c|c|}
\hline No. & Responden & Cid & $\begin{array}{c}\text { Choice } \\
\text { sets }\end{array}$ & alternatif & $\begin{array}{l}\text { Respon } \\
\text { (I) }\end{array}$ & $\mathrm{xl}$ & $x^{2}$ & $x^{3}$ & $x 4$ & $x 5$ & Usia & JK & Pekerjaan & $\begin{array}{l}\text { Pengalaman } \\
\text { Meaginap }\end{array}$ \\
\hline 1 & 1 & 1 & 1 & 2 & 0 & 1 & .1 & .1 & .1 & .1 & 22 & 0 & 0 & 0 \\
\hline 2 & 1 & 1 & 1 & 7 & 1 & .1 & 1 & 1 & .1 & .1 & 22 & 0 & 0 & 0 \\
\hline 3 & 1 & 2 & 2 & 2 & 0 & 1 & .1 & .1 & .1 & .1 & 22 & 0 & 0 & 0 \\
\hline 4 & 1 & 2 & 2 & 12 & 1 & 1 & 1 & .1 & 1 & -1 & 22 & 0 & 0 & 0 \\
\hline$\vdots$ & $\vdots$ & $\vdots$ & $\vdots$ & $\vdots$ & $\vdots$ & $\vdots$ & $\vdots$ & $\vdots$ & $\vdots$ & $\vdots$ & $\vdots$ & $\vdots$ & $\vdots$ & $\vdots$ \\
\hline 57 & 1 & 28 & 28 & 25 & 0 & -1 & -1 & -1 & 1 & 1 & 22 & 0 & 0 & 0 \\
\hline 58 & 1 & 28 & 28 & 32 & 1 & 1 & 1 & 1 & 1 & 1 & 22 & 0 & 0 & 0 \\
\hline 59 & 2 & 29 & 1 & 2 & 1 & 1 & -1 & .1 & .1 & .1 & 21 & 0 & 0 & 0 \\
\hline 60 & 2 & 29 & 1 & 7 & 0 & .1 & 1 & 1 & .1 & .1 & 21 & 0 & 0 & 0 \\
\hline$\vdots$ & $\vdots$ & $\vdots$ & $\vdots$ & $\vdots$ & $\vdots$ & $\vdots$ & $\vdots$ & $\vdots$ & $\vdots$ & $\vdots$ & $\vdots$ & $\vdots$ & $\vdots$ & $\vdots$ \\
\hline 4983 & 89 & 2492 & 28 & 25 & 0 & .1 & .1 & .1 & 1 & 1 & 50 & 1 & 1 & 1 \\
\hline 4984 & 89 & 2492 & 28 & 32 & 1 & 1 & 1 & 1 & 1 & 1 & so & 1 & 1 & 1 \\
\hline 4985 & 90 & 2493 & 1 & 2 & 1 & 1 & .1 & .1 & .1 & .1 & 27 & 1 & 1 & 1 \\
\hline 4986 & 90 & 2493 & 1 & 7 & 0 & .1 & 1 & 1 & .1 & .1 & 27 & 1 & 1 & 1 \\
\hline 4987 & 90 & 2494 & 2 & 2 & 1 & 1 & -1 & .1 & .1 & .1 & 27 & 1 & 1 & 1 \\
\hline 4988 & 90 & 2494 & 2 & 12 & 0 & 1 & 1 & -1 & 1 & -1 & 27 & 1 & 1 & 1 \\
\hline 4989 & 90 & 2495 & 3 & 2 & 0 & 1 & -1 & -1 & -1 & .1 & 27 & 1 & 1 & 1 \\
\hline$\vdots$ & $\vdots$ & $\vdots$ & $\vdots$ & $\vdots$ & $\vdots$ & $\vdots$ & $\vdots$ & $\vdots$ & $\vdots$ & $\vdots$ & $\vdots$ & $\vdots$ & $\vdots$ & $\vdots$ \\
\hline 10299 & 184 & 5150 & 26 & 22 & 0 & 1 & -1 & 1 & .1 & 1 & 23 & 0 & 1 & 1 \\
\hline 10300 & 184 & 5150 & 26 & 25 & 1 & .1 & .1 & .1 & 1 & 1 & 23 & 0 & 1 & 1 \\
\hline 10301 & 184 & 5151 & 27 & 22 & 1 & 1 & -1 & 1 & -1 & 1 & 23 & 0 & 1 & 1 \\
\hline 10302 & 184 & 5151 & 27 & 32 & 0 & 1 & 1 & 1 & 1 & 1 & 23 & 0 & 1 & 1 \\
\hline 10303 & 184 & 5152 & 28 & 25 & 1 & .1 & .1 & .1 & 1 & 1 & 23 & 0 & 1 & 1 \\
\hline 10304 & 184 & 5152 & 28 & 32 & 0 & 1 & 1 & 1 & 1 & 1 & 23 & 0 & 1 & 1 \\
\hline
\end{tabular}

Tabel 3. Pengujian Parameter Model Conditional Logistic Regression

\begin{tabular}{|l|l|}
\hline Output & Nilai \\
\hline Number of obs & 10304 \\
\hline LR $c h i^{2}(5)$ & 653,10 \\
\hline
\end{tabular}

\begin{tabular}{|l|l|}
\hline Output & Nilai \\
\hline Prob $>c h i^{2}$ & 0,000 \\
\hline Pseudo ${ }^{2}$ & 0,0914 \\
\hline
\end{tabular}

Tabel 4. Pengujian Parameter Model Conditional Logistic Regression

\begin{tabular}{|c|c|c|c|c|}
\hline $\begin{array}{c}\text { Var } \\
\text { Bebas }\end{array}$ & Coeff. & $\begin{array}{c}\text { Std. } \\
\text { Error }\end{array}$ & W & P-value \\
\hline $\mathrm{X} 1$ & 0,0527 & 0,0196 & 2,6954 & 0,007 \\
\hline $\mathrm{X} 2$ & 0,1962 & 0,0197 & 9,9567 & 0,000 \\
\hline $\mathrm{X} 3$ & 0,3388 & 0,0201 & 16,8605 & 0,000 \\
\hline $\mathrm{X} 4$ & $-0,0806$ & 0,0196 & $-4,1189$ & 0,000 \\
\hline $\mathrm{X} 5$ & 0,3028 & 0,0110 & 15,1575 & 0,000 \\
\hline
\end{tabular}

\section{Pengujian Parameter Secara Simultan}

Berdasarkan Tabel 3. nilai Prob $>c h i^{2}$ sebagai nilai signifikasi atau nilai p-value dalam pengujian simultan sebagai berikut:

Hipotesis:

$H_{0}: \beta_{1}=\beta_{2}=\cdots=\beta_{\mathrm{p}}=0$; kriteria green hotel secara bersama-sama tidak mempengaruhi pilihan responden.

$H_{1}$ : minimal terdapat satu $\beta j \neq 0$; minimal ada satu kriteria green hotel yang mempengaruhi pilihan responden.

Karena $p$-value $<\alpha$ yaitu $0,0000<0,05$, maka tolak $\mathrm{H}_{0}$ dan terima $\mathrm{H}_{1}$. Dapat dijelaskan 
bahwa minimal ada satu dari empat kriteria green hotel di Kota Bandung yang mempengaruhi ketertarikan pilihan responden dalam memilih green hotel di Kota Bandung. Oleh karena itu, untuk mengetahui kriteria green hotel mana yang berpengaruh terhadap ketertarikan pilihan responden maka perlu dilakukan pengujian parameter secara parsial.

\section{Pengujian Parameter Secara Parsial}

Berdasarkan Tabel 4. terdapat nilai koefisien dan nilai $P$-value pada masing-masing variabel bebas atribut kriteria green hotel, selanjutnya dilakukan pengujian sebagai berikut:

Hipotesis:

$H_{0}: \beta_{i}=0$; variabel bebas atribut tidak mempengaruhi pilihan responden.

$H_{1}: \beta_{i} \neq 0$; variabel bebas atribut mempengaruhi pilihan responden.

dimana $\mathrm{i}=1,2,3,4,5$

Dengan hipotesis diatas maka dapat disimpulkan bahwa:

Tabel 5. Hasil Kesimpulan Pengujian Parameter Secara Parsial

\begin{tabular}{|c|c|c|l|}
\hline $\begin{array}{c}\text { Var } \\
\text { Bebas }\end{array}$ & P-value & Kesimpulan & \multicolumn{1}{|c|}{ Artinya } \\
\hline $\mathrm{X} 1$ & 0,007 & $\mathrm{H}_{0}$ Ditolak & $\begin{array}{l}\text { Kualitas kamar hotel mempengaruhi } \\
\text { ketertarikan pilihan responden }\end{array}$ \\
\hline $\mathrm{X} 2$ & 0,000 & $\mathrm{H}_{0}$ Ditolak & $\begin{array}{l}\text { Perlengkapan mandi hotel } \\
\text { mempengaruhi ketertarikan pilihan } \\
\text { responden }\end{array}$ \\
\hline $\mathrm{X} 3$ & 0,000 & $\mathrm{H}_{0}$ Ditolak & $\begin{array}{l}\text { Perilaku tamu hotel mempengaruhi } \\
\text { ketertarikan pilihan responden }\end{array}$ \\
\hline $\mathrm{X} 4$ & 0,000 & $\mathrm{H}_{0}$ Ditolak & $\begin{array}{l}\text { Praktik pengelolaan lingkungan } \\
\text { hotel mempengaruhi ketertarikan } \\
\text { pilihan responden }\end{array}$ \\
\hline $\mathrm{X} 5$ & 0,000 & $\mathrm{H}_{0}$ Ditolak & $\begin{array}{l}\text { Ukuran Penghijauan hotel } \\
\text { mempengaruhi ketertarikan pilihan } \\
\text { responden }\end{array}$ \\
\hline
\end{tabular}

Selanjutnya model dapat digunakan untuk menentukan nilai utilitas dari masing-masing alternatif, dan nilai koefisien $\beta$ dapat digunakan untuk menentukan nilai peluang terpilihnya suatu alternatif dengan model berikut:

$$
\operatorname{Logit}\left(\pi\left(X_{i}\right)\right)=U \text { tility }=0,0527 X_{1}+0,1962 X_{2}+0,3388 X_{3}-0,0806 X_{4}+0,3028 X_{5}
$$

\section{Penaksiran Nilai Utilitas dan Peluang Keterpilihan Dari Setiap Alternatif}

Penaksiran nilai utilitas dimaksudkan sebagai langkah awal untuk menentukan nilai peluang terpilihnya suatu alternatif yang mana nantinya alternatif yang mempunyai nilai utilitas terbesar akan digunakan sebagai hasil akhir preferensi responden. Sebelumnya telah didapatkan nilai taksiran model conditional logit yang mana merupakan model taksiran untuk menghitung nilai utilitas suatu alternatif, oleh karena itu akan dihitung nilai taksiran utilitas beserta peluang terpilihnya dari setiap alternatif.

Tabel 6. Hasil Perhitungan Taksiran Utilitas Dari Setiap Alternatif

\begin{tabular}{|c|c|c|c|c|c|c|c|c|c|}
\hline No & Alternatif & $\mathbf{X}_{\mathbf{1}}$ & $\mathbf{X}_{\mathbf{2}}$ & $\mathbf{X}_{\mathbf{3}}$ & $\mathbf{X}_{\mathbf{4}}$ & $\mathbf{X}_{\mathbf{5}}$ & $\boldsymbol{U}$ Uility & $\boldsymbol{E x p}$ (Utility) & $\begin{array}{c}\text { Prob. Logit } \\
\text { Bersyarat }\end{array}$ \\
\hline 1 & A & 1 & -1 & -1 & -1 & -1 & $-0,7044979$ & 0,49436 & 0,0544 \\
\hline 2 & B & -1 & 1 & 1 & -1 & -1 & 0,2600137 & 1,29695 & 0,1426 \\
\hline 3 & C & 1 & 1 & -1 & 1 & -1 & $-0,4731289$ & 0,62305 & 0,0685 \\
\hline 4 & D & -1 & -1 & 1 & 1 & -1 & $-0,2935657$ & 0,74560 & 0,0820 \\
\hline 5 & E & -1 & 1 & -1 & -1 & 1 & 0,1880741 & 1,20692 & 0,1327 \\
\hline 6 & F & 1 & -1 & 1 & -1 & 1 & 0,5786205 & 1,78358 & 0,1962 \\
\hline 7 & G & -1 & -1 & -1 & 1 & 1 & $-0,3655053$ & 0,69385 & 0,0763 \\
\hline
\end{tabular}




\begin{tabular}{|c|c|c|c|c|c|c|c|c|c|}
\hline 8 & H & 1 & 1 & 1 & 1 & 1 & 0,8099895 & 2,24788 & 0,2472 \\
\hline \multicolumn{10}{|c|}{ Jumlah } \\
\hline
\end{tabular}

Ditunjukan bahwa alternatif yang memiliki nilai utilitas tertinggi yaitu alternatif $\mathrm{H}$ dengan nilai peluang sebesar 0,2472 . Dengan kata lain alternatif yang paling diminati oleh masyarakat umum adalah alternatif $\mathrm{H}$, yang mana rancangan kriterianya yaitu kualitas kamar mewah, perlengkapan mandi disediakan, pengunjung diwajibkan untuk menjaga lingkungan, ada praktik penggunaan plastik pada kemasan produk, dan ada penggunaan lampu dan peralatan hemat energi.

\section{Pemodelan Binomial Logistic Regression Antara Variabel Bebas Demografi Terhadap Alternatif $\mathbf{H}$}

Dari 28 choice set dalam kuesioner, terdapat sebanyak 7 choice set yang berisikan alternatif $\mathrm{H}$ sehingga akan dibuat variabel respon baru yaitu $\mathrm{Y}^{*}$ yang merupakan kumulatif banyaknya alternatif $\mathrm{H}$ yang dipilih oleh setiap responden, sehingga respon tersebut akan di regresi logistikan dengan variabel bebas demografi yaitu $\boldsymbol{Z}_{\mathbf{1}}=$ Usia, $\boldsymbol{Z}_{\mathbf{2}}=$ Jenis Kelamin, $\boldsymbol{Z}_{\mathbf{3}}=$ Pekerjaan, $\boldsymbol{Z}_{\mathbf{4}}=$ Pengalaman Menginap di Green Hotel.

Tabel 7. Output Binomial Logistic Regression

\begin{tabular}{|c|c|l|c|}
\hline \multirow{2}{*}{ Parameter } & Coef. & \multicolumn{2}{|c|}{ Criteria For Assessing Goodness Of Fit } \\
\hline Intercept & 0.1763 & \multicolumn{1}{|c|}{ Criterion } & Value \\
\hline Usia & 0.0241 & Log Likelihood & $-760,3088$ \\
\hline JK & 0.4573 & Full Log Likelihood & $-398,8074$ \\
\hline Pekerjaan & -0.4690 & & \\
\cline { 1 - 2 } Pengalaman & 0.2787 & &
\end{tabular}

\section{Pengujian Parameter Secara Simultan}

Hipotesis:

$H_{0}: \beta 1=\beta 2=\cdots=\beta p=0$; Karakteristik responden secara bersama-sama tidak mempengaruhi banyaknya setiap responden memilih alternatif ke-32.

$H_{l}$ : minimal terdapat satu $\beta j \neq 0$; minimal ada satu karakteristik responden yang mempengaruhi banyaknya setiap responden memilih alternatif ke-32.

$$
\text { Dimana } j=1,2, \ldots, p
$$

Statistik Uji:

Berdasarkan tabel 6 dapat dilihat bahwa nilai $l_{0}=-760,3088$ dan nilai $l_{p}=-398,8074$. Maka statistik uji simultan untuk binomial logit yaitu:

Kriteria Uji:

$$
G=-2 \ln \left[\frac{l_{0}}{l_{p}}\right]=-2 \ln \left[\frac{-398,8074}{-760,3088}\right]=1,29049
$$

Kesimpulan:

Tolak $\mathrm{H}_{0}$ jika $\boldsymbol{G}>\chi_{(\mathbf{1}-\boldsymbol{\alpha}) ;(\boldsymbol{p}-\mathbf{1})}^{2}$ dengan nilai $\alpha$ sebesar 0,05 .

Berdasarkan kriteria uji 1,29049 $>\chi_{(\mathbf{0 , 9 5 )} ;(4-1)}^{2}$ akan tetapi hasilnya 1,29299< 7, 815 , maka $\mathrm{H}_{1}$ diterima dan $\mathrm{H}_{0}$ ditolak. Dapat disimpulkan bahwa karakteristik responden secara bersama-sama tidak berpengaruh terhadap banyaknya setiap responden memilih alternatif $\mathrm{H}$.

\section{Kesimpulan}

Berdasarkan hasil penelitian ini dapat diambil kesimpulan bahwa:

1. Alternatif yang paling diminati oleh masyarakat umum adalah alternatif $\mathrm{H}$, yang mana rancangan kriteria green hotel-nya yaitu kualitas kamar mewah, perlengkapan mandi 
disediakan, pengunjung diwajibkan untuk menjaga lingkungan, ada praktik penggunaan plastik pada kemasan produk, dan ada penggunaan lampu dan peralatan hemat energi.

2. Setelah itu dilakukan binomial logistic regression banyaknya alternatif $\mathrm{H}$ yang dipilih oleh setiap responden $\left(\mathrm{Y}^{*}\right)$ terhadap variabel bebas demografi, diperoleh bahwa usia, jenis kelamin, pekerjaan dan pengalaman menginap di green hotel secara bersama-sama tidak berpengaruh terhadap banyaknya keterpilihan alternatif $\mathrm{H}$ dari setiap responden.

\section{Daftar Pustaka}

[1] Arikunto, Suharsimi. 1998. Prosedur Penelitian Suatu Pendekatan Praktek. Jakarta. PT. Rineka Cipta.

[2] Ben-Akiva, Moshe, dan Steven R. Lerman. 1999. Discrete Choice Analysis. United States of America.

[3] Bomberek, Zbigniew. 2009. Eco Resort: Planning and Design For The Tropic.

[4] Borg, W.R., \& Gall, M. D. (1989). Educational research 5th edition, hal: 227-230. New York: Longman.

[5] Chu, R. K. S., \& Choi, T. 2000. An Importance Performance Analysis Of Green Hotel Selection Factors.

[6] Frick, Heinz, dan Suskiyatno, Bambang. 1998. Dasar-Dasar Eko Arsitektur. Yogyakarta: Kanisius.

[7] Hosmer, D.W., \& Stanley L. 2000. Applied Logistic Regression. United States: John Wiley and Sons.

[8] Huber, J. 1997. What We Have Learned From 20 Years Of Conjoint Research: When To Used Self Expliated, Grande Pairs, Full Profiles Or Choice Experiment. Duk University. Diakses pada 28 Juli 2019.

[9] Lancsar, E., D. G. Fiebig dan A. R. Hole. 2017. Discrete Choice Experiments: A Guide to Model Specification, Estimation and Software. International Journal of PharmacoEconomics, 2-4. doi:10.1007/s40273-017-0506-4. 